\title{
The Implementation Strategies of Good Corporate Governance for Zakat Institutions in Indonesia
}

\author{
Irman Firmansyah \\ Siliwangi University \\ Abrista Devi \\ Ibn Khaldun University
}

\begin{abstract}
Zakat institutions are aimed to contribute to poverty alleviation in a country. In order to ensure that the Zakat institutions can perform well, it is urgently needed to have professional good governance. This research is aimed to find the best strategies to improve the management quality of the Zakat institutions in Indonesia. The research method used in this study comprises both qualitative and quantitative approach using Analytic Network Process. The research results show that to enhance the quality of good governance in Zakat institutions, following are the key elements. The top three main priorities in transparency principles are financial report standardization, followed by Zakat distributions transparency, and the knowledge about decision making. The top three main priorities in responsibilities principles are working compliance with SOPs, followed by prudential principles, and Shari'ah compliance. The top three main priorities in accountability principles are the effectiveness of internal control, followed by performance measurement, and competencies compliance with job descriptions. The top three main priorities in fairness principles are giving priority to the common interest, followed by equal treatment for all stakeholders, and prudential principles in asset management. To achieve all these priorities, the main strategy which should be prioritized is independent human management system, followed by having Shari'ah board and audit committee and the computerized Zakat system.
\end{abstract}

Keywords: Zakat institutions, Good Governance, Analytic Network Process

JEL Classification: L31, G34

\section{INTRODUCTION}

Zakat is one of the five pillars of Islam, which has been made obligatory by Allah for each and every Muslim to carry out. According to the basic principles of Zakat, the Zakat institution has to be established first within the Muslim society in a wellorganized way (Al-Habshi, 2005). Zakat is a worship containing two dimensions, i.e. there is hablum min alloh dimension (the relationship between human and Allah) and hablum min annas dimension (the relationship among humans). Zakat also has an important role to actualize the creation of justice in an economy through ensuring that the wealthy people in Muslim societies fulfil the requirement to pay Zakat, and then the Zakat funds should be distributed among all the mustahik of Zakat. Zainul Bahar Noor as vice chairman of Badan Amil Zakat Nasional Indonesia (BAZNAS) clearly stated that the potency of Zakat in Indonesia stands at 217 billion rupiah. The potency of Zakat funds is considered to have the capability to help the government to solve the problem of poverty in Indonesia. Unfortunately, the 
realization of Zakat fundraising has just reached $1.2 \%$ or IDR 3 billion thus far.

The great potential of Zakat funds in Indonesia attracts a great deal of attention by the management and academicians on how to improve the management quality of Zakat institutions to manage the Zakat funds professionally. The management of Zakat institutions (read: Amil) must have good knowledge about the management of Zakat and especially according to Zakat distribution. From the literature review, there are some problems encountered in Zakat institutions which have been highlighted, such as: a) Not applying the principle of accountability and transparency (Hamid, 2009), b) Charity fund managers do not have optimal quality of human resources which are competent, trustworthy, and have high level of work ethics (Azzaini, 2008), c) Muzaki's awareness level in Indonesia is still low at only $55 \%$ and, d) Bureaucratic system and good governance are still weak in regards to the management of Zakat in Indonesia, so this negatively impacts in terms of lack of accountability and transparency LAZ (Jahar, 2008).

Hence, it is important to have good corporate governance implementation to show persistence and professionalism in Zakat institutions in order to enhance public trust. A good institution is able to practice good corporate governance in their corporate management. This research is aimed to analyze good corporate governance in Indonesia, and to also identify the priorities in strategy to enhance the implementation of good corporate governance in Indonesian Zakat institutions.

\section{LITERATURE REVIEW}

\section{Zakat}

Zakat is one of the important pillars of Islam and its importance is widely known by all Muslims. Zakat is obligatory only for those who have fulfilled their basic needs and possess some surplus wealth above the value of Nisab. The person who pays Zakat is known as muzakky, and the recipient of Zakat is called mustahik. In literal terms, Mu'jam Wasith stated that the word Zakat is a basic word (mashdar). Zakat means blessed, growth, purify, and good (Qaradawi, 2006). Zakat means growth and development, and if somebody pays Zakat, it means that such a person is good.

In literal terms (lughat), Zakat means: grow, develop and blessed (HR. At-Tirmidzi) or can be translated as to cleanse or purify (QS. At-Taubah: 103). Paying Zakat because of belief in Allah undoubtedly will inherit much of goodness in life. Allah SWT says:

"Take, (O, Muhammad), from their
wealth a charity by which you
purify them and cause them
increase, and invoke (Allah's
blessings) upon them. Indeed, your
invocations are a reassurance to
them. And Allah is Hearing and
Knowing" (QS. At-Taubah: 103)

This ayah also contains another meaning, i.e. "grow" and "purify" means that the after-Zakat wealth is a blessing from Allah to muzakki (Qaradawi, 2006). On the other hand, according to Shari'ah terminology, Zakat means a certain portion of wealth paid as a charity to mustahik (or who have the right to that wealth). The word of Zakat in the form of ma'rifah (definitions) was mentioned 30 times in Al-Qur'an (Qaradawi, 2006). The word Zakat is mentioned along with shalat, except in only one ayah in Al-Qur'an, but it is still in the same context, "and they who are observant of Zakat" after the ayah "they who are during their prayer humbly submissive" (QS. Al-Mu'minun: 2 and 4).

Besides being the obligation of Islam, Zakat is also a worship that has two dimensions at once, i.e. vertically (the 
form of obedience to Allah) and horizontally (the form of income transfer to dhu'afa). In Islamic economic theory and practice, Zakat is a major distinct system that is not matched by other economic systems in the world. It is because Zakat is a regulation from AlQur'an and it has been pre-determined as to who are the persons who have the rights to receive the Zakat fund (mustahik). In Islamic economic theory, Zakat is an institution that implements fairness.

Zakat also plays its role as a fiscal mechanism. Zakat performs some of the major functions of modern public finance, which deal with social security entitlements, social assistance grants for childcare, food subsidy, education, health care, housing, and public transportation in a welfare state (Yusoff, 2012). Besides that, Zakat creates a balanced growth cycle. When a certain percentage of one's wealth is spent annually over the foregoing eight categories as prescribed in the Qur'an, Zakat has a significant economic impact on the society.

The institution of Zakat is among several instruments instituted by Islam to combat and enhance welfare in the society. Zakat helps to generate a flow of funds and recruit the necessary manpower. The word Zakat means growth, cleanness, and purity in Arabic. The Qur'an mentions the word Zakat 30 times and at three places, it appears as being commanded by God (Allah s.w.t). The importance of Zakat as an obligation on Muslims is also emphasized in many sayings of the Prophet Muhammad (pbuh). The importance of the institution may be established from a saying of the Prophet (pbuh) in which $\mathrm{He}$ (pbuh) indicates that refusing to pay it represents a rebellion against the Islamic State (Qaradawi, 2006). Hence, Zakat can be considered as an essential form of worship and spiritual purification.

Good Corporate Governance (GCG) Principles
The definition of Good Corporate Governance is 'a system which manages and controls the organizations or corporations to create value addition for all stakeholders'. According to OECD, corporate governance is the system by which business corporation is directed and controlled (OECD, 1999). The corporate governance structure specifies the distribution of rights and responsibilities among different participants in a corporation, such as the board, the managers, shareholders and other stakeholders and spells out the rules and procedures for making decisions on corporate affairs. By doing this, it also provides the structure through which the company objectives are set and the means of attaining those objectives and monitoring performance. Then, to ensure good corporate governance, some principles are required to be introduced in corporate governance implementation.

A good corporate governance principle is a reference point for all regulators (government) in developing a good corporate governance principles framework in a corporate/organization. The scope of corporate/organization involves the institution of Zakat as a charity organization which collects and distributes charity funds. The implementation of good corporate governance in Zakat institutions is expected to enhance the quality management of Zakat in internal management.

The principles of Organisation for Economic Co-operation and Development (OECD) contains that corporate governance should protect the rights of shareholders and ensure the equitable treatment of all shareholders including minority and foreign shareholders. It should also recognise the rights of other stakeholders and ensure the timely and accurate disclosure and transparency of all material matters regarding the corporation. Good corporate governance should ensure the strategic guidance of the company, the 
effective monitoring of the management by the board and the board's accountability (Hafeez, 2013).

The Islamic jurists claim that Islam as a religion is a complete code of life that covers all spheres of social, economic and legal structures including trade and commerce. The Islamic law (Shari'ah) provides a comprehensive system to cover not only religious rituals, but also many aspects of social and economic life, politics, business and contract law. The Islamic business principles direct to the business community to conduct their business in accordance with the Shari'ah rule of fair trade, honesty and justice towards others. The accumulation of wealth subject to constraint restrictions are allowed in Islamic system because wealth is regarded as a trust and a test for wise utilisation of wealth to benefit the society and poor people rather than to make wealthy more wealthier at the cost of poor (Tapanjeh, 2009).

\section{RESEARCH METHOD}

This study applies the ANP methodology in three steps. First, the questionnaires and in-depth interviews are administered and conducted respectively with scholars, experts, practitioners, and regulators of Zakat institutions in Indonesia. Second, the results of the preliminary stage are used to develop an appropriate ANP network and a relevant questionnaire to glean the necessary data from the experts and practitioners of Zakat institutions. Third, the ANP analysis is applied to set priority policy strategies in order to formulate optimal policy recommendations. From the following steps as mentioned above, ANP is a methodology with a qualitative and quantitative approach which was developed by Thomas L. Saaty and Louwis S. Vargas. The implementation of this methodology is supported by super decision software.

\section{Population and Sample}

The election of respondents/informants in this study uses purposive sampling technique by considering their understanding of Zakat good governance in Indonesia. The respondents consist of five experts and practitioners related to the topic discussed. There is no maximum or minimum quote to choose informant. The most important thing to be considered is that the respondents must have good knowledge about Zakat institutions good governance in Indonesia. The questions in the ANP questionnaire are in the form of pairwise comparison among elements in clusters to identify which aspect has the most impact (most dominant) and the scale effect from the current aspect. The numerical scale used is 1-9 as translated from the verbal valuation.

The fundamental scale of values to represent the intensities of judgments is shown in Table 1. This scale has been derived through stimulus-response theory and validated for effectiveness, not only in many applications by a number of people but also through the theoretical justification of what scale one must use in the comparison of homogeneous elements (Saaty \& Vargas, 2006).

Tabel 1. The Fundamental Scale of Absolute Numbers

\begin{tabular}{lll}
\hline & $\begin{array}{c}\text { Intensity of Definition } \\
\text { Importance }\end{array}$ & \multicolumn{1}{c}{ Explanation } \\
\hline 1 & Equal Importance & $\begin{array}{l}\text { Two activities contribute equally to } \\
\text { the objective. }\end{array}$ \\
2 & Weak & Experience and judgment slightly \\
3 & Moderate importance &
\end{tabular}




$\begin{array}{ll}4 & \text { Moderate plus } \\ 5 & \text { Strong importance } \\ 6 & \text { Strong plus } \\ 7 & \text { Very strong or Demonstrated } \\ & \\ 8 & \text { Very, very strong } \\ 9 & \text { Extreme importance }\end{array}$

favor one activity over another.

Experience and judgment strongly

favor one activity over another.

An activity is favored very strongly over another; its dominance demonstrated in practice.

The evidence favoring one activity over another is of the highest possible order of affirmation.

\section{Reciprocals if activity $i$ has one of the above of above nonzero numbers assigned to it when compared with activity $\mathrm{j}$, then $j$ has the reciprocal value when compared with i.}

Rationals Ratios arising from the scale
A reasonable assumption.

If consistency were to be forced by obtaining $n$ numerical values to span the matrix.
The informant filling the questionnaire must be accompanied by the researcher to keep the consistency of the answers given by the informant. Usually, the questions in the ANP questionnaire are large in number, so the inconsistency might happen in the answers.

\section{Data Analysis Method}

Data obtained from the research is analyzed through the ANP method. ANP is one tool which is commonly used in the various qualitative studies involving decision making, forecasting, evaluation, mapping, strategizing and resource allocation, for instance. ANP has three main functions, as follows:

\section{a. Complexity Structuring}

Saaty and Vargas (2006) in their research use the same form of example on how humans solve the complex problems each period of time. The complexity was structured in the hierarchy form into homogenous clusters (Saaty \& Vargas, 2006).

\section{b. Ratio scale measurement}

Previous decision-making methodology commonly uses lowlevel measurement (ordinal or interval measurement), while ANP methodology uses ratio scale measurement that is believed to be the most accurate in measuring some factors forming hierarchies. The measurement level from the lowest to the highest is nominal, ordinal, interval, and ratio. Each measurement level has the entire meaning which had the lowest level of new additional meaning. Interval measurement has no ratio meaning but has interval meaning, ordinal, and nominal. Ratio measurement is required to identify the proportion. To keep the simplicity of ANP methodology, the ratio valuation is used for every pariwise factors in the hierarchy to measure ratio scale measurement (indirect in giving the value) (Saaty \& Vargas, 2006). Each methodology with hierarchy structure must use ratio scale priority for the element above 
the lowest level of the hierarchy. It is important because the priority (or weight) from each element in every element from the hierarchy is determined by multiplying priorities from an element in a level with priority in its top element. The multiplying result from the two interval-level measurements mathematically has no meaning. The ratio scale is required in this multiplication step. ANP uses ratio scale in each of the lowest levels of hierarchy/network and includes the lowest level (alternative in the determined model). A ratio scale is more important if the priority is used not only in the determined application, but also in another application, such as resource allocation cases.

c. Synthesis

Synthesis is the opposite of analysis. If analysis means material entity or abstract into its elements, then synthesis means to unite all parts as one. The complexity, decision making, forecasting and resource allocation often involves too many dimensions for humans to do the synthesis intuitively. Thus, we need one way to do the synthesis from too many dimensions. Although ANP facilitates analysis function, the most important function in ANP is its capability to help us in doing the measurement and synthesis of some factors in hierarchies or networks.

\section{Geometric Mean}

The geometric mean is the average of set products which shows the tendentious or determined value which has the formula as follow (Ascarya, 2011):

$$
\begin{array}{r}
\left(\prod_{i}^{n}=1 a_{i}\right)^{1 / n}= \\
\sqrt[n]{a_{1}} a_{2 . .} a_{n}
\end{array}
$$

\section{Rater Agreement}

Rater agreement is a measure of the degree of agreement among raters (informant/respondents R1$\mathrm{Rn})$. It gives a score of how much homogeneity, or consensus there is in the ratings given by the judges. The tool used to measure rater agreement is Kendall's Coefficient of Concordance (W; $0<\mathrm{W} \leq 1)$. $\mathrm{W}=1$ shows perfect agreement among raters (Ascarya, 2011). To calculate Kendall's (W), the first step is to give the ranking for each answer and then calculate the total value.

$$
R_{i}=\sum_{j}^{m}=1 r_{i, j}
$$

The average value of total ranking is:

$$
R=\frac{1}{2} m(n+1)
$$

The sum of deviation quadratic (S) is calculated with the formula:

$$
S=\sum_{i}^{n}=\mathbf{1}\left(R_{i}-\bar{R}\right)^{2}
$$
as follows:

And then, Kendall's W is obtained

$$
W=\frac{12 S}{m^{2}\left(n^{3}-n\right)}
$$

If the value of $\mathrm{W}$ is $1 \quad(\mathrm{~W}=1)$, we can conclude that the valuation or the opinion of the respondents have a perfect agreement (totally agreed to the case). While if the $\mathrm{W}$ value is 0 or closer to 0 , then it shows disagreement among the respondents, or the respondents have various answers about the problems (Ascarya, 2011). 


\section{RESULT AND DISCUSSION}

Decomposition of the problems (model decomposition) is obtained from literature related to good corporate governance in Zakat institutions and also obtained from an in-depth interview from some experts who have good knowledge about good corporate governance in Zakat institutions in Indonesia. Results found some strategies of good corporate governance in Zakat institutions. Good corporate governance principles involve transparency, accountability, responsibility, and fairness. The result shows that there are some priorities which can be used to enhance good corporate governance of Zakat institutions in Indonesia. The priorities result from each cluster of GCG principles are as follows:

1. Cluster of transparency consists of clear information access, clarity of vision and mission, easy access for supervisors, financial information, standardized financial statements, knowledge of decision making, objectivity of data collecting and transparency of Zakat distribution.
2. Cluster of accountability consists of clear job descriptions, competency compliance with job desk, deep attention to job desk, good documentation, the leader must report regularly, performance measurement, effectiveness of internal control and working with business ethics.

3. Cluster of responsibility consists of CSR, avoiding harmful activities, compliance with the law and basic principles, prudential principles, Shari'ah compliance and working compliance with SOPs.

4. Cluster of fairness consists of clearity of muzakki rights, devotion to the common interest, equal treatment of all stakeholders, prudential principle in asset management and regulations to protect muzakki.

From the decomposition result, the Good Corporate Governance strategies in Zakat institutions network using ANP methodology can be formed as follows: 


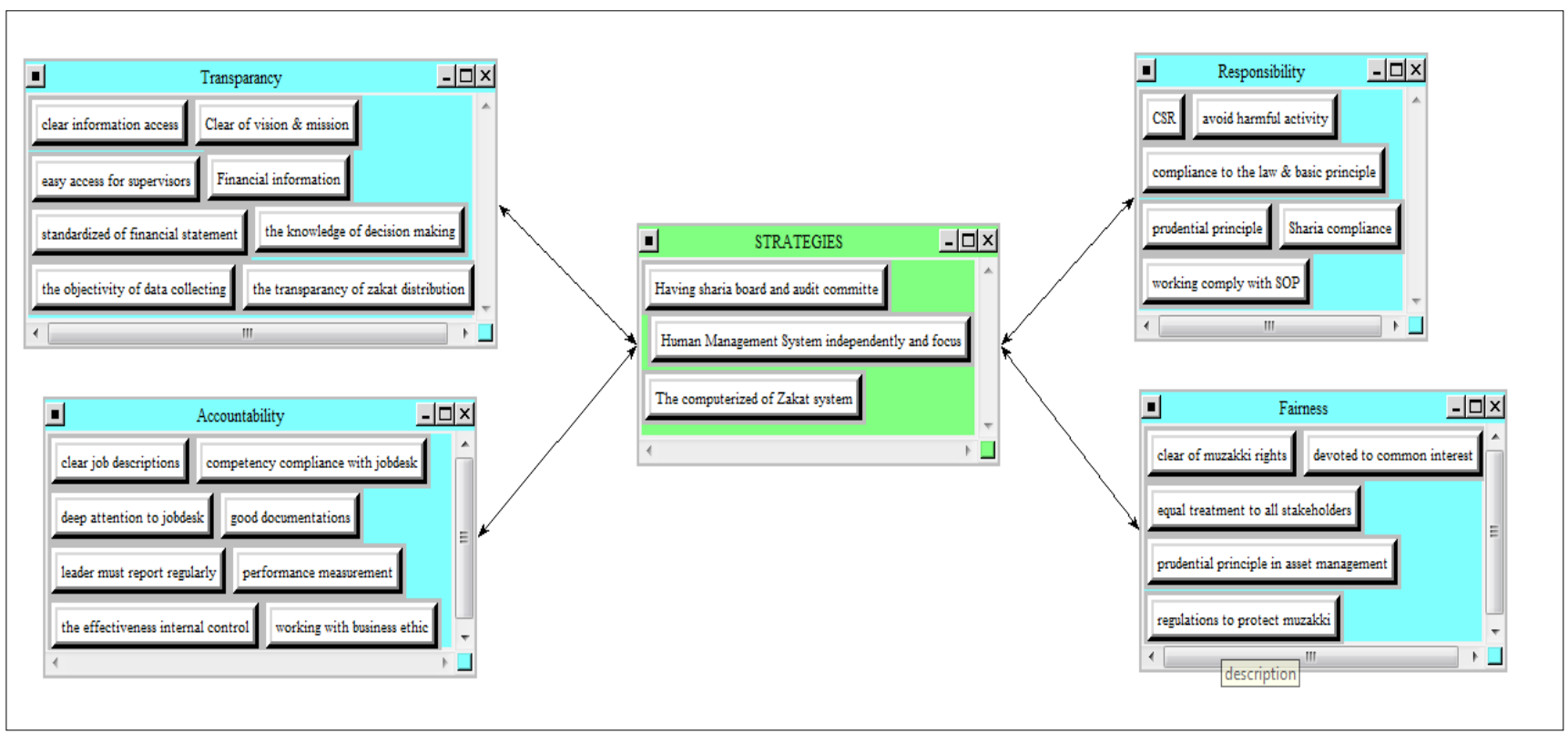

Figure 1. ANP Network Model

According to the consensus result from all the respondents, it can be found that from 4 GCG principles, there are some priorities which can be used to enhance good corporate governance of Zakat institutions in Indonesia. The first principle is transparency. The most important priority that must be taken into account to increase transparency is financial statements standardization. A good financial statement complies with its concerned regulatory standards and it will provide clear and comprehensive information regarding all the activities of the Zakat institutions. In Indonesia, the Indonesian Institute of Accountants has published the standards regarding the financial statements of Zakat institutions. This standard must be used by the Zakat institutions as a form of good corporate governance in providing transparent information to all societies, especially to muzakki.

The second priority is the transparency of Zakat distribution. It shows that Zakat distribution is an important activity in Zakat institutions as per the respondents' consensus. The level of trust of muzakki in the institutions is going to increase if Zakat institutions are able to provide transparent information regarding where the Zakat has been distributed supported by effective reporting in financial statements. Zakat funds distributed through a transparent system means that the Zakat institutions have distributed to all the parties who have the rights to receive the Zakat funds (mustahik) and there should be no hidden activities unknown to mustahik of Zakat.

The third priority is the knowledge about decision making. The management of Zakat institutions must have good knowledge about the urgent problems in decision making. This is important because external parties of Zakat institutions will give their complete trust to the management, and the public does not expect any mistake to happen in decision making, especially with regards to two main activities of the institutions as managers and distributors of the Zakat fund. In addition, the knowledge about decision making is also important for internal management of Zakat institutions itself which will build safe and comfortable atmosphere if the important problem is decided very speedily and appropriately. More detail about the other priorities is presented in Figure 2. 


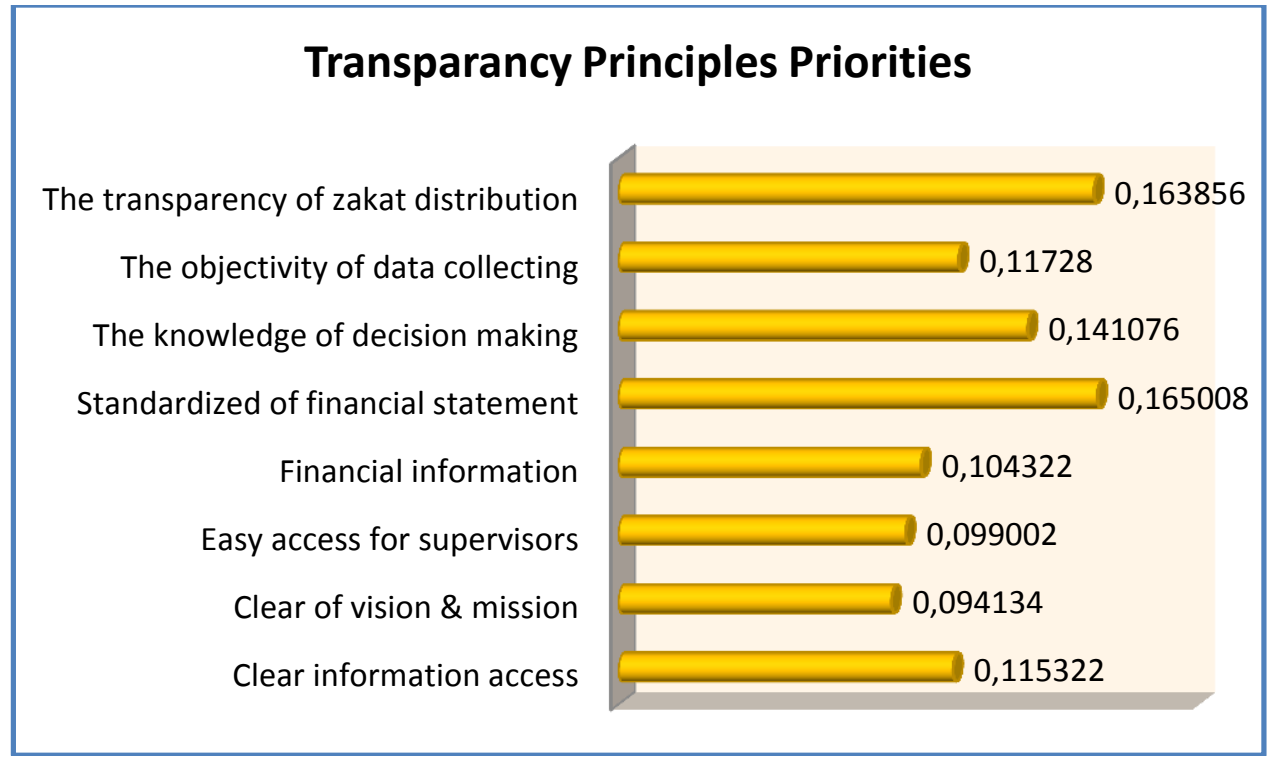

Figure 2. Transparency Principles Priorities

The second GCG principle in Zakat institutions is responsibilities. In order to increase the responsibilities of institutions, the important priorities of this cluster are working compliance with operational procedure standards. Operational procedure standards or commonly known as SOPs are created by institutions in order to enhance the management capability in ensuring compliance with operations with determined requirements and standards. It is aimed to achieve orderly work and good productivity. Hence, this priority is a top priority as a responsibility form of good corporate governance.

The second priority is to follow the prudential principle. Working properly and orderly is a requirement of being prudential in carrying out various jobs. A fault that occurs due to the lack of prudence in doing the job is affected by the low responsibility for a task assigned. Hence, running the prudential principle will directly increase individual responsibility to the institutions, and ensure individual responsibility to the public.

The third priority is Shari'ah compliance. As institutions whose purpose is to help muzakki in distributing their Zakat, the management of Zakat institutions should run all of their activities based on Shari'ah compliance, starting from the procedures of Zakat acceptance form muzakki, the management of Zakat fund, and Zakat distribution. More detail about the other priorities is presented in Figure 3. 


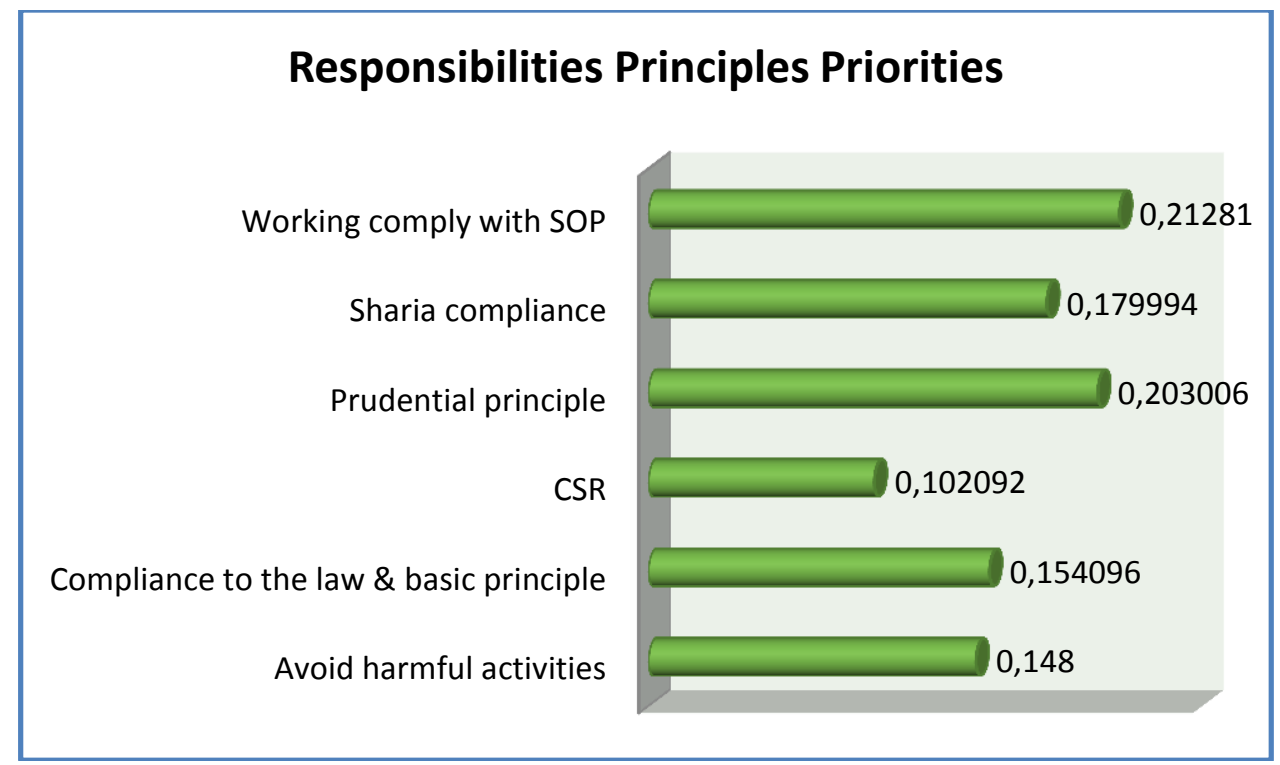

Figure 3. Responsibilities Principles Priorities

The third GCG principle in Zakat institutions is accountability. The main priorities that urgently need to be done in order to increase Zakat institutions accountability are internal control effectiveness. Internal control is important considering that human error can always happen anywhere including Shari' ah based management institutions. In order to keep the management always working with Shari'ah compliance or regulation compliance, it needs good internal control. Respondents view that the internal control effectiveness is considered as the most important factor to achieve good accountability as a form of responsibilities to the public.

The second priority is performance measurement. In order to ensure whether the accountability that has been implemented complies with the determined standards, the Zakat institutions must have the measurement of their performance. Performance measurement can be implemented across all managers and institutions. The absence of performance measurement will affect the institutions' ability to value their performance, and then indicators of measurement would remain absent. In order to maintain and increase the operational performance of Zakat institutions, the performance measurement must be assessed for each period. Evaluation strategies regarding Zakat institutions development must be informed frequently to the public especially to muzakki.

The third priority is competency compliance with the job description. According to the respondents' consensus, it is required to have competencies which comply with the job description in order to achieve the Zakat institutions accountability improvement. Competency is important to complete a job adequately with required resources on demand. In terms of corporate governance, it is required to have expertise in management, accounting and other fields so that the Zakat institutions follow and improve the accountability principles easily. More details about the other priorities are presented in Figure 4. 


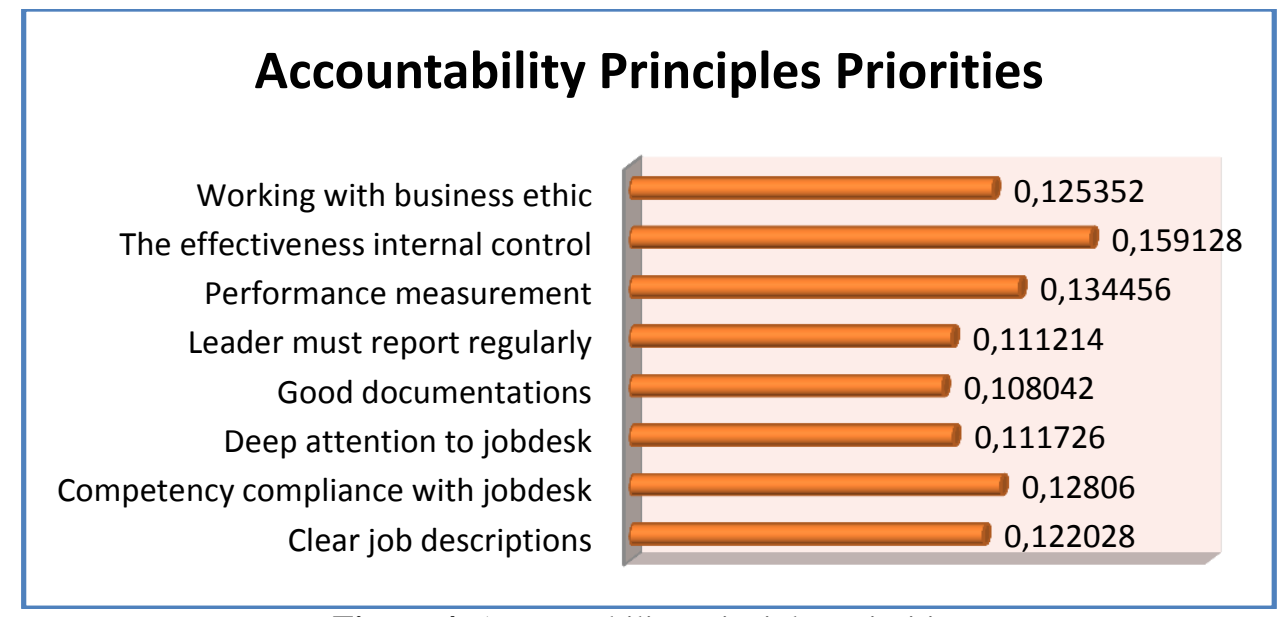

Figure 4. Accountability Principles Priorities

The fourth GCG principle is fairness. The main priorities that are urgently needed to be done in order to increase Zakat institutions fairness are devoted to common interest. If the institutions are devoted to the common interest, then it will be fair to all parties. The fairness of a job is ensuring that a job complies with the task. In a situation where no party is wrong, then it will create a comfortable and conducive atmosphere. In addition, fairness can be perceived also by the public, especially muzakki. Muzakki must perceive that the Zakat funds are wellmanaged by the institution to create the fairness to external parties.

The second priority is equal treatment to all stakeholders. Respondents feel important that the institution must treat equally to all stakeholders, not only for muzakki but also to all managers and the public. Good corporate governance of Zakat institutions is clearly different with other institutions (especially for-profit organizations) because Zakat institutions must be based on Shari'ah compliance, which upholds the principle of justice.

The third priority is to follow the prudential principle in asset management. Assets controlled by Zakat institutions including assets in the form of funds taken from muzakki and the assets owned by the institution must be managed well. Current assets (funds collected) from the public must be maintained properly because Zakat institutions are mandated with the task to distribute these funds to the mustahik. While the management of other assets such as fixed asset owned by the institutions also must be maintained properly because if a mistake happens in managing the asset, it will decrease public trust to Zakat institutions management. More details about the other priorities are presented in Figure 5.

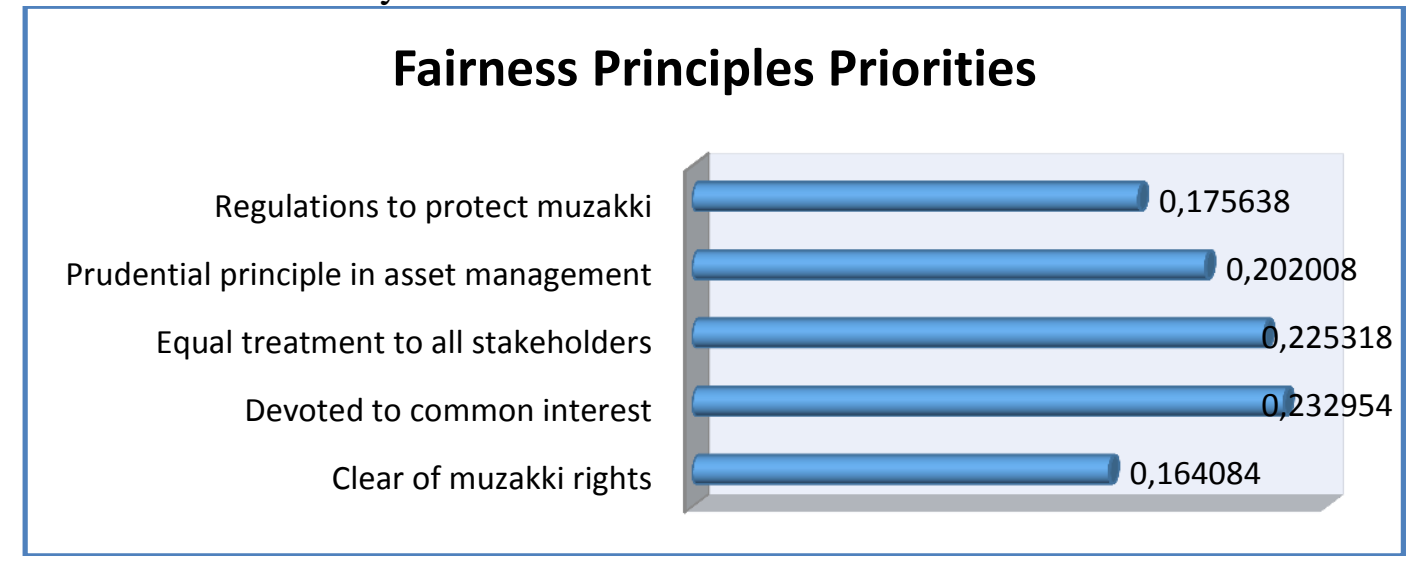

Figure 5. Fairness Principles Priorities 
To obtain the most important priorities in each GCG principles of Zakat institutions in Indonesia as already explained above, it is required to have best strategies alternatives. According to consensus result from all the expert respondents, there are three best strategies, namely (a) Having Shari'ah Board and Audit Committee, (b) Independent and Focused Human Management System, and (c) The Computerized Zakat System.

Based on those three strategies as mentioned earlier, all the respondents agree that the main strategy to enhance the capability of Zakat management institutions to implement GCG is Human Management System independence and focus. This explains that to create good corporate governance, the priority must be on the party who manages the institutions itself (human resource). To obtain the good human resource, good recruitment is required which is free from the interest of certain parties. The next step is to make good human resource management system which is free from the intervention of certain parties. Then, the human resource will be focused on the job (managing Zakat institutions in order to achieve good corporate governance in Zakat institutions).

The second most priority strategy is Having Shari'ah Board and Audit Committee and this is followed by the computerized Zakat system. More details about the other priorities of alternative strategies are presented in Figure 6.

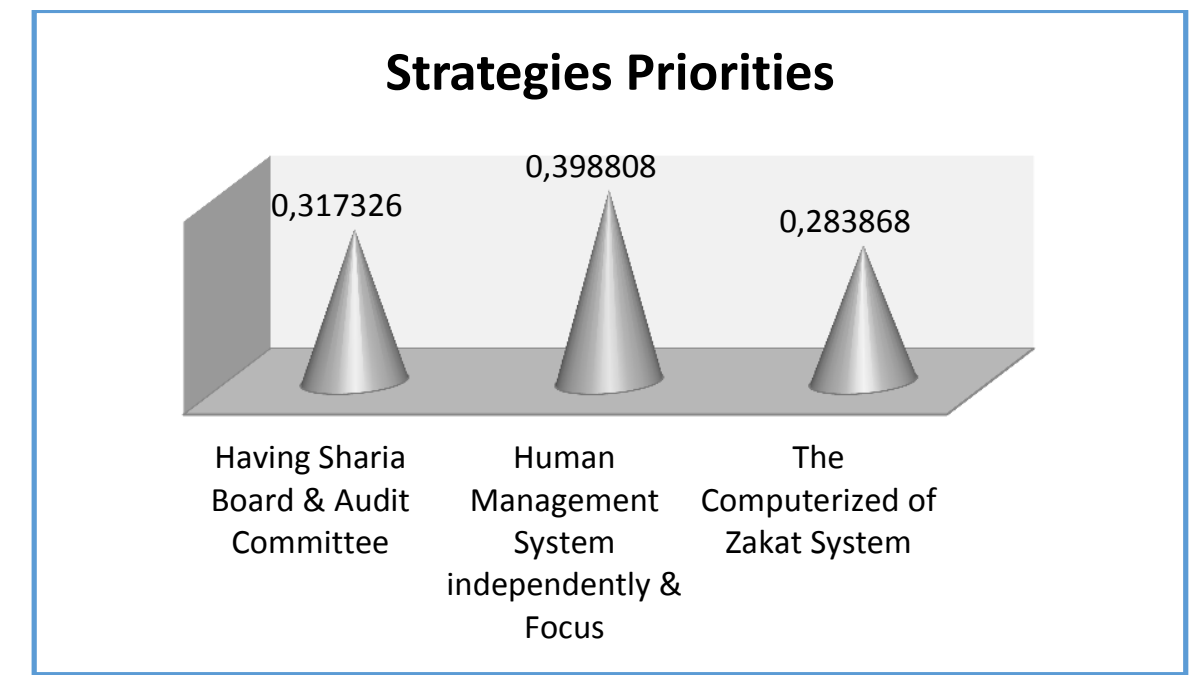

Figure 6. Strategies Priorities of GCG Implementation in Indonesia Zakat Institutions

The average value of Kendall's Coefficient of Concordance (W) in entire respondents' answers is $0.993(99.3 \%)$. This value is closer to $100 \%$ and it means that all respondents have a good level of agreement (high agreement level) on the priorities answers given in every cluster of GCG principles.

\section{CONCLUSIONS}

Based on the result of this research and the discussion regarding Zakat institutions GCG practices in Indonesia, we can conclude with the following important points:

1. There are four GCG principles in Indonesia Zakat institutions; these are transparency, accountability, responsibility, and fairness.

2. To obtain the transparency, Zakat institutions have to create financial statement standards, followed by transparency in Zakat distribution and 
knowledge about decision making.

3. To obtain the responsibility, Zakat institutions have to work in compliance with the current SOPs, followed by prudential principles and Shari'ah compliance.

4. To obtain the accountability, Zakat institutions have to increase the internal control effectiveness, followed by performance measurement and human skill compliance with job descriptions.

5. To obtain the fairness, Zakat institutions have to give priority to the common interest, followed by equal treatment to all parties (all stakeholders) and prudential principles in asset management.

6. The alternative strategies priorities can be used to achieve good corporate governance include independent and focused human management system, having a Shari'ah Board and Audit Committee, and finally having a computerized Zakat System.

\section{REFERENCES}

Al-Habshi, S. M. (2005). Zakat recognition and measurement of business wealth: an analysis of the growth condition, Ins. Shanmugam et al. (edit.), Issues in

Islamic Accounting. Serdang: University Putra Malaysia Press.

Ascarya. (2011). The Persistence of Low Profit and Loss Sharing Financing in Islamic Banking: The Case of Indonesia. Review of Indonesian economic and business studies, 1 .

Azzaini, J. (2008). Empower Institute Amil Zakat, p. 5.
Hafeez, M. M. (2013). An Analysis of Corporate Governance in Islamic and Western Perspective. International Journal of Business, Economic and Law, 2(3), 6.

Hamid, A. (2009). He fate of Amil Zakat Institutions in Indonesia, Republika, p. 10 \& 13.

Jahar, A. S. (2008). Zakat Between Muslim Nations: Considering Position Realistic Government and Civil Society Organizations. Media Journal Zakat dan Empowerment, $1,2$.

OECD. (1999). Business Sector Advisory Group on Corporate Governance.

Qaradawi, Y. (2006). Fiqh al-Zakat - A Comparative Study of Zakat, Regulations and Philosophy in The Light of Quran and Sunnah. Kingdom of Saudi Arabia, Jeddah: King Abdul Aziz University

Saaty, T. L., \& Vargas, L. G. (2006). Decision Making with the Analytic Network Process. USA: Springer.

Tapanjeh, A. M. A. (2009). Corporate Governance from the Islamic Perspective: A Comparative analysis with OECD principles. Critical Perspectives on Accounting, 20, 11.

Yusoff, M. B. (2012). Zakat distribution and growth in the federal territory of Malaysia. Journal of Economics and Behavioral Studies, 4(8), 8 .

Irman Firmansyah

Siliwangi University

Indonesia

Abrista Devi

Ibn Khaldun University

Indonesia 
